\title{
Learning Processes for Digital Storytelling Scientific Imagination
}

\author{
Ming-Min Cheng ${ }^{1}$, Hsueh-Hua Chuang ${ }^{1 *}$ \\ ${ }^{1}$ National Sun Yat-Sen University, Kaohsiung, TAIWAN
}

Received 2 March 2018 - Revised 28 June 2018 - Accepted 16 July 2018

\begin{abstract}
This article discusses an implementation research study that examined participating students' learning processes of scientific imagination in a marine science digital storytelling (DST) project. Twenty-two fourth-grade students in a primary school participated in the study. Data were collected via students' completed worksheets, digital storyboards, final digital storytelling products, and interviews. Results revealed that the lowest student performance occurred during the Dynamic Adjustment stage among the five stages of the digital storytelling scientific imagination framework. Students were not proficient in describing the relationships among scientific concepts and creating science stories based on their science knowledge. We also found opportunities for using DST tools in the conceptualization, organization, and formation of developing scientific imagination. The results suggested that interactive learning environments and fluent digital literacy are crucial in improving students' ability to explore and connect different ideas in the development of scientific imagination.
\end{abstract}

Keywords: digital storytelling, scientific imagination, learning processes, marine science

\section{INTRODUCTION}

Remarkable advancements in technology have had an enormous impact on our everyday lives and play a critical role in teaching and learning. Technology, when used as a tool for personal and social reflection and creation, can help learners become independent, life-long seekers and constructors of knowledge (Jonassen, 2013). Ho, Wang, and Cheng (2013) defined imagination as a human ability, the basis for all creative activities, and the result of cognitive and emotional processes. Hacieminoglu (2016) indicated that imagination, creativity, and being open to new ideas are all important in scientific pursuits. That is, imagination leads humans to seek and discover the unknown. All tremendous inventions originated from imagination. Humans have constructed scientific theories and created new inventions to improve life by considering experiences and converting them into imagination. Imagination can affect our experiences and thinking by enhancing an individual's ability to conceptualize, enhancing links to reality, inducing creative inventions, and provoking improvement of society based on life experiences (Fleer, 2013). Ho et al. (2013) further proposed that scientific imagination is the desire to deal with difficulties in life and solve problems based on the operation of imagination. Scientific imagination boosts mental activity toward developing novel ideas by connecting scientific phenomena with life experiences. It is neither limited by rules nor impeded by modes of intrinsic thinking (Wang, Ho, \& Cheng, 2015).

Digital storytelling (DST) is a classroom application defined as telling stories through use of multimedia technology (Duman \& Göcen, 2015). DST is produced by collecting pictures and videos, taping videos, and taking photographs, and then integrating the points of view or even the experiences that the points of view represent (Alrutz, 2013; Niemi \& Multisilta, 2016). DST helps students develop their creativity for solving problems and enhances their learning motivation, while also providing opportunities for students to express their thoughts and experience different perspectives (Ohler, 2008; Reijnders, 2010; Smeda, Dakich, \& Sharda, 2014). Thus, digital storytelling is a tool for enhancing students' imaginations to provide students with opportunities to reconstruct

(C) 2019 by the authors; licensee Modestum Ltd., UK. This article is an open access article distributed under the terms and conditions of the Creative Commons Attribution License (http://creativecommons.org/licenses/by/4.0/). \mingmin058@gmail.com 


\section{Contribution of this paper to the literature}

- This is the first article to integrate two concepts, digital storytelling and scientific imagination, as the theoretical framework for guiding the development of each of the five constructs of the digital storytelling scientific imagination framework.

- The study provides a detailed digital storytelling scientific imagination rubric for evaluating students' learning performances in a technology-integrated marine science curriculum.

- The results indicated that students exhibited little proficiency with the lowest performance in the dynamic stage of the digital storytelling scientific imagination framework in describing relationships among science concepts when creating a prototype for a digital story.

knowledge, present the best of themselves, and enhance their learning processes. In addition, digital stories can open up a path to creativity and collaboration (Ohler, 2008; Ranieri \& Bruni, 2013).

This study implemented scientific imagination as guidance for connecting learners' science knowledge and life experiences. In addition, we adopted digital storytelling as a tool for facilitating science knowledge construction and for stimulating students' learning attitudes and motivation while also helping students reconstruct knowledge and evaluate their learning processes. The study focused on revealing student learning processes through the lens of a digital storytelling scientific imagination framework.

\section{DIGITAL STORYTELLING SCIENTIFIC IMAGINATION FRAMEWORK}

According to previous research studies, digital storytelling has four stages: pre-production, production, postproduction, and distribution (Chung, 2006; Ohler, 2006; Robin, 2008; Sharda, 2007; Yang \& Wu, 2012). Smeda et al. (2014) adapted the criteria and framework constructed by Houston University (2011) and developed an e-Learning Digital Storytelling (eLDiST) framework based on 13 aspects: plot, pacing and narratives, dramatic question, story characters, emotional content, purpose, language usage, story content, technological competence, production, presentation, economy of content, and evaluation. The practice of digital storytelling also provides opportunities for learners to think critically and construct new knowledge from life experiences while presenting concepts $(\mathrm{Xu}$, Park, \& Baek, 2011). Digital storytelling can also enhance students' digital and media literacy, 21st-century ability, academic achievement, and engagement (Gredori-Signes, 2013; Hung, Hwang, \& Huang, 2012; Niemi \& Multisilta, 2016; Rebeiro, 2016; Yang \& Wu, 2012). Story-making is a way to integrate knowledge with life experiences to develop learners' digital literacy and reconstruct knowledge they have learned. It is also believed that scientific imagination approaches can enhance an individual's conceptualization abilities, provide a link to reality, induce creative inventions, and enhance improvement of society based on life experiences (Fleer, 2013).

Ho et al. (2013), by studying five exemplary teachers' perspectives on how the teachers prepared students for the International Exhibition for Young Inventors (IEYI), explored mechanisms and factors that influence the scientific imagination processes of elementary school students. They found that scientific imagination has three stages: (1) The initiation stage is composed of brainstorming to focus on many ideas that could be generated to solve the problem. (2) The dynamic adjustment stage has two components: association in which students identify as many relationships as possible among ideas, followed by transformation and elaboration in which students give new meaning to ideas and transform them into novel ideas. (3) The virtual implementation stage is composed of conceptualization, organization, and formation. In this final stage, students may refine particular ideas and formulate inventions to solve the problem.

We developed a digital storytelling scientific imagination framework based on Ho et al.'s (2013) three stages of scientific imagination, Smeda et al.'s (2014) eLDiST framework, and the four stages of digital storytelling: preproduction, production, post-production, and distribution. Thus, the digital storytelling scientific imagination framework is composed of five stages: brainstorming, dynamic adjustment, virtual practice, practice, and display (see Table 1).

Brainstorming is the first stage. In this stage, students identify problems related to a scientific subject, such as natural phenomena and generated aspects, and arrive at solutions to the problems according to the students' experiences. The concept has three components. First, students deal with the problem in accordance with science subjects they might have encountered. For example, a student may first arrive at the reason why a shark was lying on a beach by noting that the shark's fin was cut. Second, based on the first component, students can infer the influence on the living environment (e.g., if sharks were facing extinction, the ocean food chain might be unbalanced). Third, students select the best solution for solving a scientific problem by exploring various novel ideas (e.g., the government could enact a law to protect sharks from extinction). 
Table 1. Digital storytelling scientific imagination framework

\begin{tabular}{ll}
\hline Stages & Concept \\
\hline Brainstorming stage & $\begin{array}{l}\text { Students can speak up the problems related to the subject of science and the solutions to the problems } \\
\text { according to their life experiences. }\end{array}$ \\
\hline $\begin{array}{l}\text { Dynamic Adjustment } \\
\text { stage }\end{array}$ & $\begin{array}{l}\text { Students can make digital science stories in a specific scientific theme/subject based on their science } \\
\text { knowledge; besides, they can brainstorm the contents of stories, describe the relationships among the } \\
\text { key concepts critically to express his/her comprehension of the specific scientific concept. }\end{array}$ \\
\hline Virtual Practice stage & $\begin{array}{l}\text { Students can consider the possibilities about the implementation of making digital science stories (e.g., } \\
\text { story points, contents, digital materials, technologies etc.), and reorganize the stories according to the } \\
\text { science knowledge and technological skills that they learned. }\end{array}$ \\
\hline Practice stage & $\begin{array}{l}\text { Students can collect and use a variety of digital materials (e.g., pictures, drawings, sounds, music, } \\
\text { animation, video clips, texts etc.), and choose computer editing software programs to make digital } \\
\text { science stories to be uploaded to the internet. }\end{array}$ \\
\hline Display stage & $\begin{array}{l}\text { Students can utilize multimedia programs (e.g., computer software, internet platforms, mobile devices) to } \\
\text { present their digital science stories. }\end{array}$ \\
\hline
\end{tabular}

Dynamic Adjustment is the second stage. Students brainstorm ideas and describe relationships among the concepts to express comprehension of a specific scientific concept. Students also generate stories related to a specific scientific theme based on the students' science knowledge. Students then refine their previous activities to create prototypes reflecting specific ideas. Furthermore, the prototype should include the material, the desired functions, and the purposes of creating a design using initial diagrams. Students design a story based on scientific knowledge to express their capability of comprehending specific scientific concepts and describing relationships among the key concepts. Such a story is usually created using scientific knowledge the students have learned, such as themes, relationships among key points, and plots. Students present their own science knowledge through storytelling.

Virtual Practice is the third stage. In this stage, students consider the possibilities of making scientific digital stories based on science knowledge the students may have learned in more depth, such as story points, content, materials, and technologies. Such stories can be designed to show what students have learned and what they care about. Through the process of making digital stories (e.g., plots, content, and narrative), students express their points of view and moreover, clarify their own science knowledge through organizing the story to conceptualize their knowledge.

Practice is the fourth stage. Students collect digital materials, such as pictures, sounds, music, video clips, etc. Depending to the students' storyboards and the materials collected, students utilize computer editing software to create digital stories to be uploaded to the Internet.

Display is the fifth stage. Students can utilize multimedia programs (e.g., computer software, internet platforms, mobile devices) to present their digital science stories.

\section{PURPOSE OF THE STUDY}

The purpose of this study is to reveal the learning processes of learners engaged in a marine science digital storytelling project. The research questions are as follows:

i. What are the student performances and the learning processes at each stage of the digital storytelling scientific imagination framework?

ii. What challenges and opportunities emerge when students engage in a digital storytelling scientific imagination practice?

\section{METHODOLOGY}

\section{Mixed Methods}

Mixed-methods research refers to the type of study in which qualitative and quantitative datasets are mixed based on the assumption that combining quantitative and qualitative approaches in a research project provides a better understanding of the problem being investigated than a separate approach would (Creswell \& Plano Clark, 2011). Therefore, quantitative and qualitative data are collected and analyzed in a single study or a series of studies.

To answer the two research questions, the study employed what Creswell and Plano Clark (2011) proposed: a mixed method convergent design to collect, analyze, and interpret the data from different data sources. In this study, quantitative data consisted of ratings of the artifacts of students' completed worksheets, digital storyboards, and final digital storytelling products based on digital storytelling scientific imagination rubrics. Details of the student artifact collection are presented in Table 2. Qualitative data consisted of semi-structured interviews with 
Table 2. Students' artifact collections

\begin{tabular}{|c|c|c|}
\hline Stage & Artifacts & Activities \\
\hline Brainstorming & Worksheets & $\begin{array}{l}\text { Situation: } \\
\text { "There is a school on the island. The school is located near the beach. There is a shark lying } \\
\text { on the beach..." Please answer the following questions. } \\
\text { 1. Question: What problems might the situation bring about? (the more problems, the } \\
\text { better) } \\
\text { 2. Question: What influences might the problems bring about to our life? (the more } \\
\text { Influences, the better) } \\
\text { 3. Question: How many solutions could you think of? (the more solutions, the better) }\end{array}$ \\
\hline \multirow{2}{*}{$\begin{array}{l}\text { Dynamic } \\
\text { Adjustment }\end{array}$} & Worksheets & $\begin{array}{l}\text { Following the same situation, please draw one "new invention" that you think can solve the } \\
\text { problem in the situation. You have to explain what materials you need for your new } \\
\text { invention and specify the functions of the invention. }\end{array}$ \\
\hline & Four-grid comic & $\begin{array}{l}\text { Situation: } \\
\text { "A fisherman saved a sea turtle from being bullied by a bunch of children." Please complete } \\
\text { the following story. }\end{array}$ \\
\hline Virtual Practice & $\begin{array}{l}\text { Digital storytelling } \\
\text { storyboards }\end{array}$ & $\begin{array}{l}\text { Chose a scientific theme constructed in specific marine life (week } 1 \text { to week } 4 \text { ) classes, } \\
\text { making stories with specific marine scientific theme, in which concluded drawing and script. }\end{array}$ \\
\hline Practice & $\begin{array}{l}\text { Digital storytelling } \\
\text { products }\end{array}$ & $\begin{array}{l}\text { According to their digital storytelling storyboards, students collect multimedia materials } \\
\text { (e.g. images, music, video clips etc.) and utilize computer editing software program to make } \\
\text { digital storytelling product. }\end{array}$ \\
\hline Display & & Students present their digital storytelling product by multimedia. \\
\hline
\end{tabular}

participating students and their answers to open-ended questions on the worksheets. With this design, different but complementary data are collected, and the data are integrated by combining the qualitative data in the form of texts or images with the quantitative data in the form of numeric information. In other words, the results from the quantitative analysis can be compared and contrasted with the qualitative findings.

\section{Participants}

The 9-week marine science digital storytelling learning project was designed by content experts from the Marine Science College and received pedagogical support from the Institute of Education. The participants were fourthgrade students in a primary school in a southern metropolitan city in Taiwan. Twenty-two students (10 male and 12 female) were divided into five groups, with each group consisting of 4 to 5 students and a teaching assistant.

\section{Project Procedure}

The researchers and instructors collaboratively designed a 9-week marine science digital storytelling project for fourth-grade students based on the digital storytelling scientific imagination framework. Teaching assistants providing assistance to each group of students during the lesson included five graduate students from the Institute of Education. The project was conducted for 2 hours each week over a 9-week period from March to May 2016.

The project involved four marine theme concepts (exotic species, land crab, sea turtle, and shark), leading to the delivery of a final digital storytelling product as one learning outcome. The purpose of the week 1 to week 4 activity was to construct students' marine science knowledge on themes of marine organism and to promote scientific imagination through completing scientific imagination learning activities. Marine science knowledge, such as specific ocean animals' living habits, the animals' importance to nature, and their relationships with nature, other marine organisms, and humankind were included. Scientific imagination learning activities were conducted at the end of each lesson, with the purpose of each activity to deepen the marine science knowledge students learned and to promote students' scientific imagination. Students, guided by instructors and teaching assistants, were expected to give as many ideas and solutions as possible to advance the students' level of scientific imagination development.

The period from week 5 to week 8 focused on developing students' digital storytelling abilities. Students were asked to select a specific marine science-related theme for designing a storyboard for their digital storytelling project, and they were engaged in story arrangement of plots, narrators, characters, and science phenomena facilitated by the teaching assistants. The students then embarked on digital storytelling creation, including collecting multimedia materials, utilizing computer editing software, and uploading digital stories to the Internet platform. In the final week (week 9), each student shared and presented his or her digital story to the class. 


\section{Data Collection}

Using the digital storytelling scientific imagination framework as a guide, we developed learning activities (filling out worksheets, completing a four-grid comic, working on storyboards, and telling a digital story) to map different stages of the framework (see Table 2). Students were allocated assignments and tasks in every class, and we collected the students' completed worksheets, digital storyboards, and final digital storytelling products. To better explore the students' learning processes of digital storytelling based on scientific imagination, interviews with students were also conducted. Table 2 describes the details of the student artifact collection. Thirty-minute interviews were conducted in focus groups by each teaching assistant. The interview outline was designed to coordinate closely with the digital storytelling scientific imagination framework to interpret the student learning processes and performances. Students were informed that the interviews would be recorded.

\section{Data Analysis}

Student worksheets, storyboards, and digital storytelling products were evaluated to provide insights into the students' achievement during each stage of the digital storytelling scientific imagination framework and to display their learning processes. The artifacts were coded based on digital storytelling scientific imagination rubrics. Thus, the quantitative data consisted of ratings of the artifacts of the students' completed worksheets, digital storyboards, and final digital storytelling products. The scoring scale ranged from 0 to 3 with 3 the highest score and 0 the lowest (see Table 3). The coding was performed three times by each of three raters within a month. To reach consensus, raters were asked to explain their underlying reasons for the scores during the second coding process. The coding was revised after the second coding based on each rater's common understanding. The inter-rater reliability of the rubrics was $r=0.97$. The inter-rater reliability of each stages are as follows: the Brainstorming stage, $r=0.96$; the Dynamic Adjustment stage, $r=0.95$; the Virtual Practice stage, $r=0.96$; the Practice stage, $r=0.99$; and the Display stage, $r=1.00$. See Table 4 .

Table 3. Digital storytelling scientific imagination rubrics as generative tools

\begin{tabular}{|c|c|c|c|}
\hline Stage & Mission & Score & Performances \\
\hline \multirow{12}{*}{$\begin{array}{l}\text { Brain- } \\
\text { storming }\end{array}$} & \multirow{4}{*}{$\begin{array}{l}1-1 \\
\text { Identify the } \\
\text { potential scientific } \\
\text { problems. }\end{array}$} & 0 & Students cannot list the problems related to the scientific subjects. \\
\hline & & 1 & Students can list one problem related to the scientific subjects. \\
\hline & & 2 & Students can list two problems related to the scientific subjects. \\
\hline & & 3 & Students can list more than three problems related to the scientific subjects. \\
\hline & \multirow{4}{*}{$\begin{array}{l}1-2 \\
\text { Specify the } \\
\text { influence induced } \\
\text { by the problems } \\
\text { toward our life. }\end{array}$} & 0 & Students cannot list the causes of science problems influence in life. \\
\hline & & 1 & Students can list one cause of science problems influence in life. \\
\hline & & 2 & Students can list two causes of science problems influence in life. \\
\hline & & 3 & Students can list more than three causes of science problems influence in life. \\
\hline & \multirow{4}{*}{$\begin{array}{l}1-3 \\
\text { Provide solutions } \\
\text { to problems. }\end{array}$} & 0 & Students cannot list the solutions to the science problems in life. \\
\hline & & 1 & Students can list one solution to the science problems in life. \\
\hline & & 2 & Students can list two solutions to the science problems in life. \\
\hline & & 3 & Students can list more than three solutions to the science problems in life. \\
\hline \multirow{12}{*}{$\begin{array}{l}\text { Dynamic } \\
\text { Adjustment }\end{array}$} & \multirow{4}{*}{$\begin{array}{l}2-1 \\
\text { Draw new } \\
\text { invention for } \\
\text { solving the } \\
\text { problem. }\end{array}$} & 0 & $\begin{array}{l}\text { Students cannot draw a invention includes its function, materials, and prototype to solve } \\
\text { specific science problem. }\end{array}$ \\
\hline & & 1 & $\begin{array}{l}\text { Students can draw a prototype to solve specific science problem, cannot explain its } \\
\text { function or materials; Students can explain the invention's function or materials to solve } \\
\text { specific science problem, cannot draw its prototype. }\end{array}$ \\
\hline & & 2 & $\begin{array}{l}\text { Students can draw a prototype and illustrate its function and materials to solve specific } \\
\text { science problem. }\end{array}$ \\
\hline & & 3 & $\begin{array}{l}\text { Students can draw a creative prototype (e.g., novel functions, special ideas) and illustrate } \\
\text { its function and materials to solve specific science problem. }\end{array}$ \\
\hline & \multirow{4}{*}{$\begin{array}{l}2-2 \\
\text { t Draw new } \\
\text { invention for } \\
\text { solving the } \\
\text { problem. }\end{array}$} & 0 & Students cannot list object's function to solve specific science problem. \\
\hline & & 1 & Students can list one object to solve specific science problem. \\
\hline & & 2 & Students can combine two objects to solve specific science problem. \\
\hline & & 3 & Students can combine more than three objects to solve specific science problem. \\
\hline & \multirow{4}{*}{$\begin{array}{l}2-3 \\
\text { Complete an } \\
\text { unfinished comic. }\end{array}$} & 0 & Students cannot design story based on the science knowledge they learned. \\
\hline & & & $\begin{array}{l}\text { Students can design a simple story structure, rather than having logic based on the } \\
\text { science knowledge they learned. }\end{array}$ \\
\hline & & 2 & Students can design a logical story based on the science knowledge they learned. \\
\hline & & 3 & $\begin{array}{l}\text { Students can design a not only logical but novel story based on the science knowledge } \\
\text { they learned. }\end{array}$ \\
\hline
\end{tabular}


Table 3 (continued). Digital storytelling scientific imagination rubrics as generative tools

\begin{tabular}{|c|c|c|c|}
\hline Stage & Mission & Score & Performances \\
\hline \multirow{12}{*}{$\begin{array}{l}\text { Virtual } \\
\text { Practice }\end{array}$} & \multirow{4}{*}{$\begin{array}{l}\text { 3-1 } \\
\text { Design the } \\
\text { characters in } \\
\text { storyboard }\end{array}$} & 0 & Students cannot design the character in storyboard. \\
\hline & & 1 & Students can design one character in storyboard. \\
\hline & & 2 & Students can design two characters in storyboard. \\
\hline & & 3 & Students can design more than three characters in storyboard. \\
\hline & \multirow{4}{*}{$\begin{array}{l}3-2 \\
\text { Design narrator in } \\
\text { storyboard }\end{array}$} & 0 & Students cannot design background narrator in storyboard. \\
\hline & & 1 & Students can design a simple background narrator structure, rather than having logic. \\
\hline & & 2 & Students can design a logical background narrator. \\
\hline & & 3 & Students can design a not only logical but novel background narrator. \\
\hline & \multirow{4}{*}{$\begin{array}{l}3-3 \\
\text { Design a } \\
\text { storyboard based } \\
\text { on the science } \\
\text { knowledge they } \\
\text { learned }\end{array}$} & 0 & Students cannot design storyboard based on the science knowledge they learned. \\
\hline & & 1 & $\begin{array}{l}\text { Students can design a simple storyboard structure based on the science knowledge they } \\
\text { learned, rather than having logic. }\end{array}$ \\
\hline & & 2 & Students can design a logical storyboard based on the science knowledge they learned. \\
\hline & & 3 & $\begin{array}{l}\text { Students can design a logical and novel storyboard based on the science knowledge } \\
\text { they learned. }\end{array}$ \\
\hline \multirow{20}{*}{ Practice } & \multirow{4}{*}{$\begin{array}{l}4-1 \\
\text { Collect multiple } \\
\text { materials to make } \\
\text { digital story }\end{array}$} & 0 & $\begin{array}{l}\text { Students cannot collect multiple materials (e.g., pictures, drawings, sounds, music, } \\
\text { animation, video clips etc.) to make digital story; Students can only use multiple } \\
\text { materials provided by teacher to make digital story. }\end{array}$ \\
\hline & & 1 & Students can collect static materials (e.g., pictures, draws, texts etc.) to make digital story. \\
\hline & & 2 & $\begin{array}{l}\text { Students can collect dynamic materials (e.g., sounds, music, animation, video clips etc.) } \\
\text { to make digital story. }\end{array}$ \\
\hline & & 3 & $\begin{array}{l}\text { Students can collect multiple materials (e. g., pictures, drawings, sounds, music, } \\
\text { animation, video clips etc.) to make digital story. }\end{array}$ \\
\hline & \multirow{4}{*}{$\begin{array}{l}4-2 \\
\text { Use multiple } \\
\text { materials to make } \\
\text { digital story }\end{array}$} & 0 & $\begin{array}{l}\text { Students cannot use multiple materials (e.g., pictures, drawings, sounds, music, } \\
\text { animation, video clips etc.) to make digital story. }\end{array}$ \\
\hline & & 1 & Students can use static materials (e.g., pictures, draws, texts etc.) to make digital story. \\
\hline & & 2 & $\begin{array}{l}\text { Students can use dynamic materials (e.g., sounds, music, animation, video clips etc.) to } \\
\text { make digital story. }\end{array}$ \\
\hline & & 3 & $\begin{array}{l}\text { Students can use multiple materials (e.g., pictures, drawings, sounds, music, animation, } \\
\text { video clips etc.) to make digital story. }\end{array}$ \\
\hline & \multirow{4}{*}{$\begin{array}{l}4-3 \\
\text { Use computer } \\
\text { editing software } \\
\text { program to make } \\
\text { digital story }\end{array}$} & 0 & Students cannot use computer editing software program to make digital story \\
\hline & & 1 & $\begin{array}{l}\text { Students can use basic computer editing software program (e.g., PowerPoint, Movie } \\
\text { Maker, or iMovie) to make digital story. }\end{array}$ \\
\hline & & 2 & $\begin{array}{l}\text { Students can use advanced computer editing software program (e.g., Cyberlink Power } \\
\text { Director or Adobe Premire) to make digital story. }\end{array}$ \\
\hline & & 3 & $\begin{array}{l}\text { Students can use the mobile devices (e. g., smart phones, or tablets) to make digital } \\
\text { story. }\end{array}$ \\
\hline & \multirow{4}{*}{$\begin{array}{l}4-4 \\
\text { Design characters } \\
\text { in digital story }\end{array}$} & 0 & Students cannot design the character in digital story. \\
\hline & & 1 & Students can design one character in digital story. \\
\hline & & 2 & Students can design two characters in digital story. \\
\hline & & 3 & Students can design more than three characters in digital story. \\
\hline & \multirow{4}{*}{$\begin{array}{l}4-5 \\
\text { Design digital } \\
\text { story based on the } \\
\text { science knowledge } \\
\text { they learned }\end{array}$} & 0 & Students cannot design a digital story based on the science knowledge they learned. \\
\hline & & 1 & $\begin{array}{l}\text { Students can design a simple digital story structure based on the science knowledge } \\
\text { they learned, rather than having logic. }\end{array}$ \\
\hline & & 2 & Students can design a logical digital story based on the science knowledge they learned. \\
\hline & & 3 & $\begin{array}{l}\text { Students can design a logical and novel digital story based on the science knowledge } \\
\text { they learned. }\end{array}$ \\
\hline \multirow{3}{*}{ Display } & \multirow{3}{*}{$\begin{array}{l}5-1 \\
\text { Digital story } \\
\text { display }\end{array}$} & 0 & Students cannot use multimedia programs to present their digital story. \\
\hline & & 1 & $\begin{array}{l}\text { Students can use computer software (e.g., PowerPoint, Windows Media Player, or iMovie) } \\
\text { to present their digital story. }\end{array}$ \\
\hline & & 2 & $\begin{array}{l}\text { Students can use internet platforms (e.g., YouTube, or Facebook) to present their digital } \\
\text { story. }\end{array}$ \\
\hline
\end{tabular}


Table 4. Inter-rater reliability of digital storytelling scientific imagination framework rubrics

\begin{tabular}{llc}
\hline CONSTRUCT & INDEX & $\begin{array}{c}\text { Kendall } \\
\text { Coefficient of } \\
\text { Concordance }\end{array}$ \\
\hline Brainstorming & $\begin{array}{l}\text { Students can speak up the problems related to the subject of science and the solutions to } \\
\text { the problems according to their life experiences. }\end{array}$ & .96 \\
\hline $\begin{array}{l}\text { Dynamic } \\
\text { Adjustment }\end{array}$ & $\begin{array}{l}\text { Students can make digital science stories in a specific scientific theme/subject based on } \\
\text { their science knowledge; besides, they can brainstorm the contents of stories, describe the } \\
\text { relationships among the key concepts critically to express his/her comprehension of the } \\
\text { specific scientific concept. }\end{array}$ & .95 \\
\hline Virtual Practice & $\begin{array}{l}\text { Students can consider the possibilities about the implementation of making digital science } \\
\text { stories (e.g., story points, contents, digital materials, technologies etc.), and reorganize the } \\
\text { stories according to the science knowledge and technological skills that they learned. }\end{array}$ & .96 \\
\hline \multirow{3}{*}{ Practice } & $\begin{array}{l}\text { Students can collect and use a variety of digital materials (e.g., pictures, drawings, sounds, } \\
\text { music, animation, video clips, texts etc.), choose computer editing software program to } \\
\text { make their digital science stories, and upload their stories to the internet. }\end{array}$ & .99 \\
\hline Display & $\begin{array}{l}\text { Students can utilize the multimedia programs (e.g., computer software, internet platforms, } \\
\text { mobile devices) to present their digital science stories. }\end{array}$ & 1.00 \\
\hline Total & & .97 \\
\hline
\end{tabular}

Students' answers to the open-ended questions in the worksheets were organized and coded in accordance with five stages of the framework. We then analyzed the interview transcripts and coded data by grouping information of particular relevance using thematic analysis to allow qualitative themes to emerge. The interview coded segments were then compared and triangulated with other data sources such as students' worksheets, storyboards, and final digital storytelling products.

To respond to the first research question, students' learning processes were clarified by the students' performances in completing the worksheets and collecting digital story artifacts by raters who assigned a score for students' performances at each stage of the digital storytelling scientific imagination framework. Student interviews as qualitative data also provided additional evidences that increased the validity of the interpretation of the students' learning processes. This integration consisted of combining the quantitative data in the form of numeric information with qualitative data in the form of texts or images (Creswell \& Plano Clark, 2011). To respond to the second research question in identifying challenges and opportunities when students engage in a digital storytelling scientific imagination practice, qualitative themes identified a typology of differing challenges and opportunities from the participating students' learning process and performances.

\section{RESULTS AND DISCUSSION}

\section{General Profile of Students' Average Performance in Each Stage}

Student artifacts were analyzed to illustrate the level of their learning performance of digital storytelling scientific imagination in marine science (see Figure 1 and Table 5). In the Brainstorming stage, a maximum of 9 points ( 3 points for each item) represented a student able to identify problems related to more than three science subjects and find solutions to the problems based on his or her life. The average score in this stage was 5.73 out of a total of $9(M=5.73, S D=1.91)$, reflecting a $64 \%(5.73 / 9)$ of the total possible performance in the Brainstorming stage. 


\section{Students' Performances}

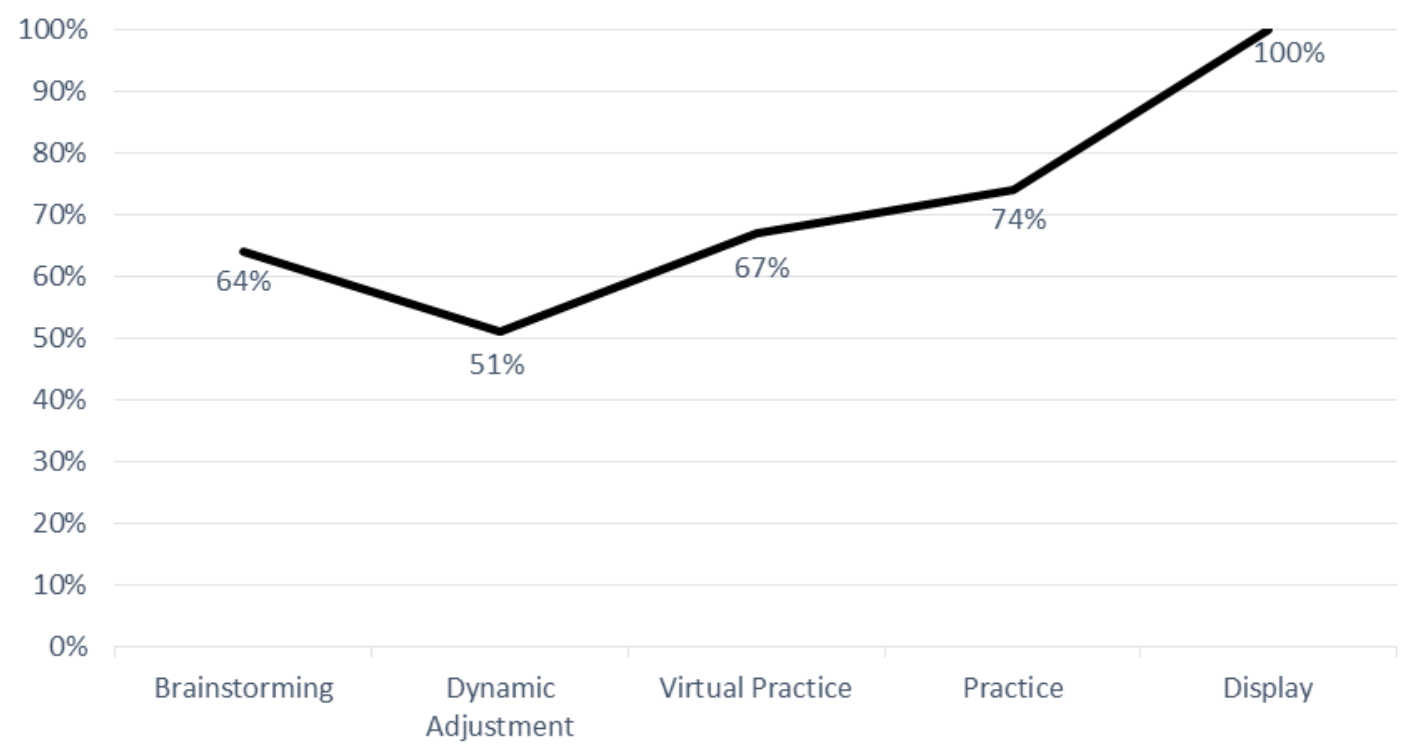

Figure 1. The average of student development in digital storytelling scientific imagination throughout the program

Table 5. Descriptive results of student performances

\begin{tabular}{llcccc}
\hline Stages & $\mathbf{N}$ & Max points & Mean points & SD & \% \\
\hline Brainstorming & 22 & 9 & 5.73 & 1.91 & 64 \\
\hline Dynamic Adjustment & 22 & 9 & 4.55 & 1.87 & 51 \\
\hline Virtual Practice & 22 & 9 & 6.00 & 1.51 & 67 \\
\hline Practice & 22 & 15 & 11.14 & 1.13 & 74 \\
\hline Display & 22 & 2 & 2.00 & 0.00 & 100 \\
\hline
\end{tabular}

The Dynamic Adjustment stage embodies student comprehension of specific science concepts by telling stories and inventing prototypes. The maximum points for this stage was 9, representing the maximum capability of designing a detailed prototype with materials and functions, and completing a fixed structure story with logic, creativity, and the science knowledge they have learned. The average student score was 4.55 out of a total of 9 ( $M$ $=4.55, S D=1.87$ ) in this stage, indicating $51 \%$ of the total possible performance. Most students achieved an average performance at this stage. Only one student achieved the maximum 9 points in expressing his grasp of diverse concepts by illustrating the prototype and creating a story. In contrast, five students with scores of only 3 or 4 points experienced difficulty in connecting different concepts and expressing their creativity through the task at this stage.

During the Virtual Practice stage, a storyboard provided an imaginary space for students to express their understanding of a specific science subject to demonstrate understanding of science subjects and scientific imagination without restriction. The maximum possible score was 9, and a student achieving 9 points would be able to create a story that integrates science knowledge and creativity. After discussing and revising the storyboards in class, the students scored an average of 6.00 out of a total of $9.00(M=6.00, S D=1.51)$ at this stage, indicating an achievement of $67 \%$ of the total possible performance.

In the Practice stage, students who received 15 points (the maximum) would be expected to be able to collect multiple materials (e.g., pictures, video clips, and music) and use computer editing software to create digital stories that correspond to a storyboard. The average student score was 11.14 out of the maximum 15.00 points, indicating $74 \%$ of the total possible performance.

The Display stage reflects student utilization of technology devices to present digital storytelling artifacts and illustrate understanding of science concepts. The maximum score is 2 . Students who could use the Internet platform to present their work received 2 points. A student's performance of $100 \%$ indicates the capability of presenting work with multimedia (e.g., YouTube and WeExplore). Interviews were conducted in the final week of the program to reveal students' authentic presentation abilities, and results are presented in the following section. 


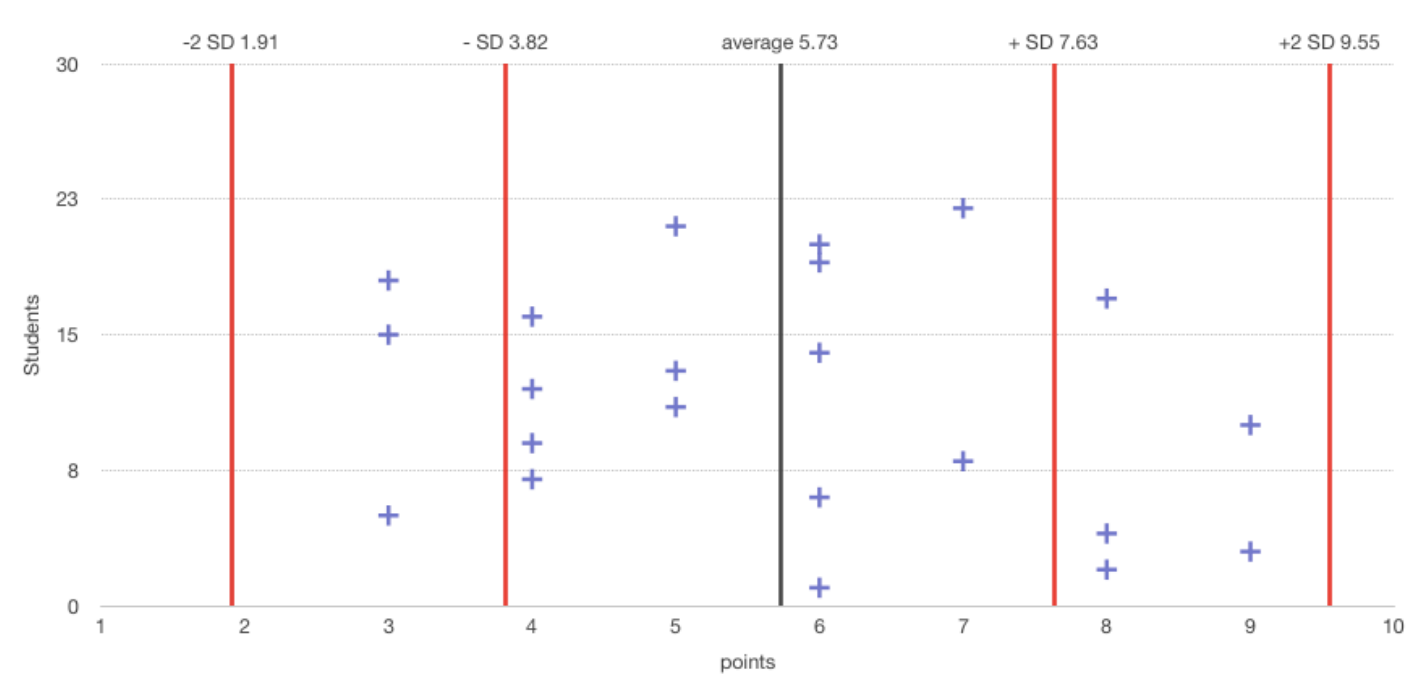

Figure 2. The distribution of students' performance in the Brainstorming stage

*Note: each + symbol represents a student $(N=22)$. Line 3.82 represents a standard deviation less than mean; line 7.63 represents a standard deviation above the mean

\section{Student Performances in the Brainstorming Stage}

Students were asked to identify potential scientific problems based on a hypothetical situation in which a shark is lying on a beach. Students then specified the impact such science problems might have on the environment and provide solutions to these problems (see Table 2). We focused on whether students could identify scientific problems, comprehend associations among concepts, and demonstrate capability of solving the specific science problems. The distribution of student performances in the Brainstorming stage indicated that most $(\mathrm{N}=14)$ performed between within one standard deviation of the mean, three students performed a standard deviation lower than the mean, and five students performed more than one standard deviation above the mean (see Figure 2).

Five students who performed a standard deviation above the mean demonstrated superior ability in associating scientific subjects with the marine environment with knowledge the students had learned previously. In responding to mission 1-1 and 1-2 (see Table 3), students' capability for identifying potential scientific problems and specifying the influence induced by the problems was examined. The students listed more than three problems related to the scientific subjects. For example, the shark was dead because its fin was cut, the shark was stuck in a fish net, a straw was stuck in the shark's gill slit, and the shark swam near the beach to hunt fish. The students were also able to list more than three consequences of these science problems. For example, one student stated, "Catching the shark might cause the destruction of food chain, the reduction of little fish, the extinction of shark species, etc." They also exhibited greater concern for the marine environment on their worksheets and in the focus interview. In the Brainstorming stage, mission 1-3 was to provide solutions to problems, and students who exhibited better performance listed more solutions than other students, with some stating, "Stop eating shark fins," and "Sharks should be listed as a conservation species." Several also proposed eating farmed fish to promote marine protection: "Shark is one of the species in the circulation of the nature" (student interview group 2). "If we keep over fishing for shark or cut its fin, shark will face with extinction and cause the destruction of the food chain" (student interview group 3).

However, three students who performed at a standard deviation lower than the mean listed only one problem related to the scientific subject. For example, one said, "The shark is lying on the beach because it's dead." They also tended to answer problems unrelated to the given situation, and typically, listed only one consequence of the science problem. One student listed two consequences, including that the increasing number of fish would make the ships hard to sail, and this would create the problem that ships would not sail near the beach. This answer is obviously unreasonable. Regarding the solutions to the science problem, students often could not find the best solution to the science problems, and sometimes, even stated irrelevant solutions, such as "Move the shark to another place" or "Heal the shark and put it back in the ocean." 


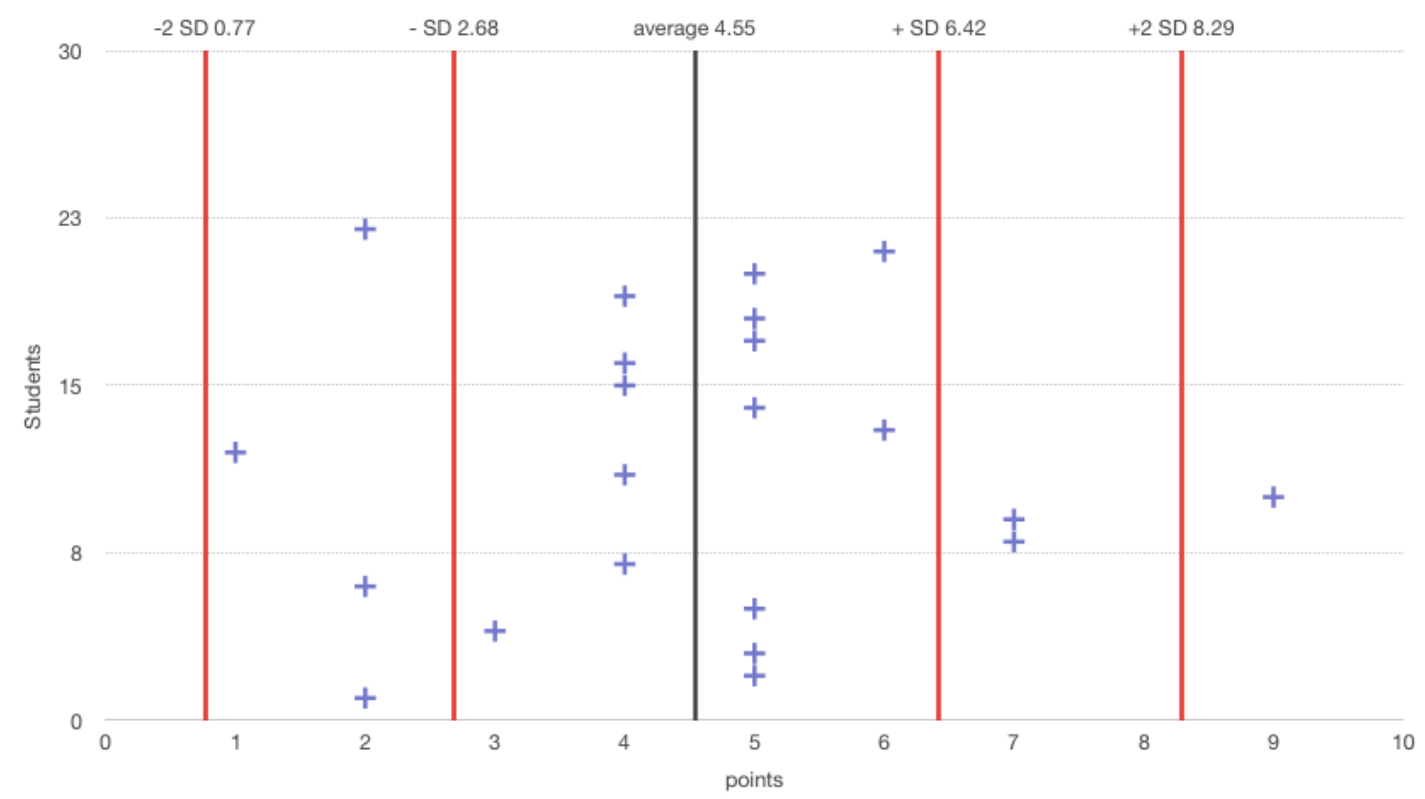

Figure 3. The distribution of students' performance in Dynamic Adjustment stage

${ }^{*}$ Note: each + symbol represents a student $(N=22)$. Line 2.68 represents a standard deviation less than the mean; line 6.42 represents a standard deviation above the mean

\section{Student Performances in the Dynamic Adjustment Stage}

In the Dynamic Adjustment stage, following the same situation as in the Brainstorming stage, students were asked to draw one invention to solve the problem and then explain the materials needed and the functions of the invention. In addition, the students had to complete a four-grid comic about "a fisherman saved a sea turtle from being bullied by a bunch of children". The distribution of student performance revealed that 14 of the 22 students performed within one standard deviation of the mean, four students performed at one standard deviation lower than the mean, two students performed at one standard deviation above the mean, and one student performed at two standard deviation above the mean (see Figure 3).

Although most students were able to present an invention for solving the problem by drawing a prototype and illustrating its functions and materials for solving specific science problems, the students listed only one material item for building the machine. One student drew a shark-protecting tank full of water with a generator to protect sharks from being hunted by humans. However, the materials (the water and generator) that student presented made it difficult to illustrate the invention's function.

Meanwhile, three students showed greater capability in association and comprehension than the others, and one student's performance in particular surpassed the others'. This student drew a creative prototype, illustrated the function, and combined more than three materials to solve the specific science problem. The student invented magical gauze to help the shark heal from injuries and recover its fin from being cut. The materials the student used were gauze, magical powder, and a wood slab to fix the bone. Such students were able to specify their ideas by presenting the materials and functions the students used to solve the problem (see Table 6). 
Table 6. A student's prototype task of inventing a prototype to illustrate his/her understanding of specific concepts which perform higher than one SD to the mean

Mission 2-1, 2-2 Following the same situation, please draw one "new invention" that you think can solve the problem in the situation, explain what materials you need for your new invention, and specify the functions of the invention (the more detail, the better).

Questions
$\begin{aligned} & \text { What problem you want to Shark's fin can recover } \\
& \text { solve? }\end{aligned}$
\begin{tabular}{ll} 
What materials you need & gauze, magical powder, and a \\
wor the invention? & wood slab to fix the bone \\
\hline $\begin{array}{l}\text { What are the functions of } \\
\text { Shark can heal from injuries and } \\
\text { the invention? }\end{array}$ & Magical gauze
\end{tabular}
$\begin{aligned} & \text { What is the invention? } \\
& \text { Man from being cut. }\end{aligned}$

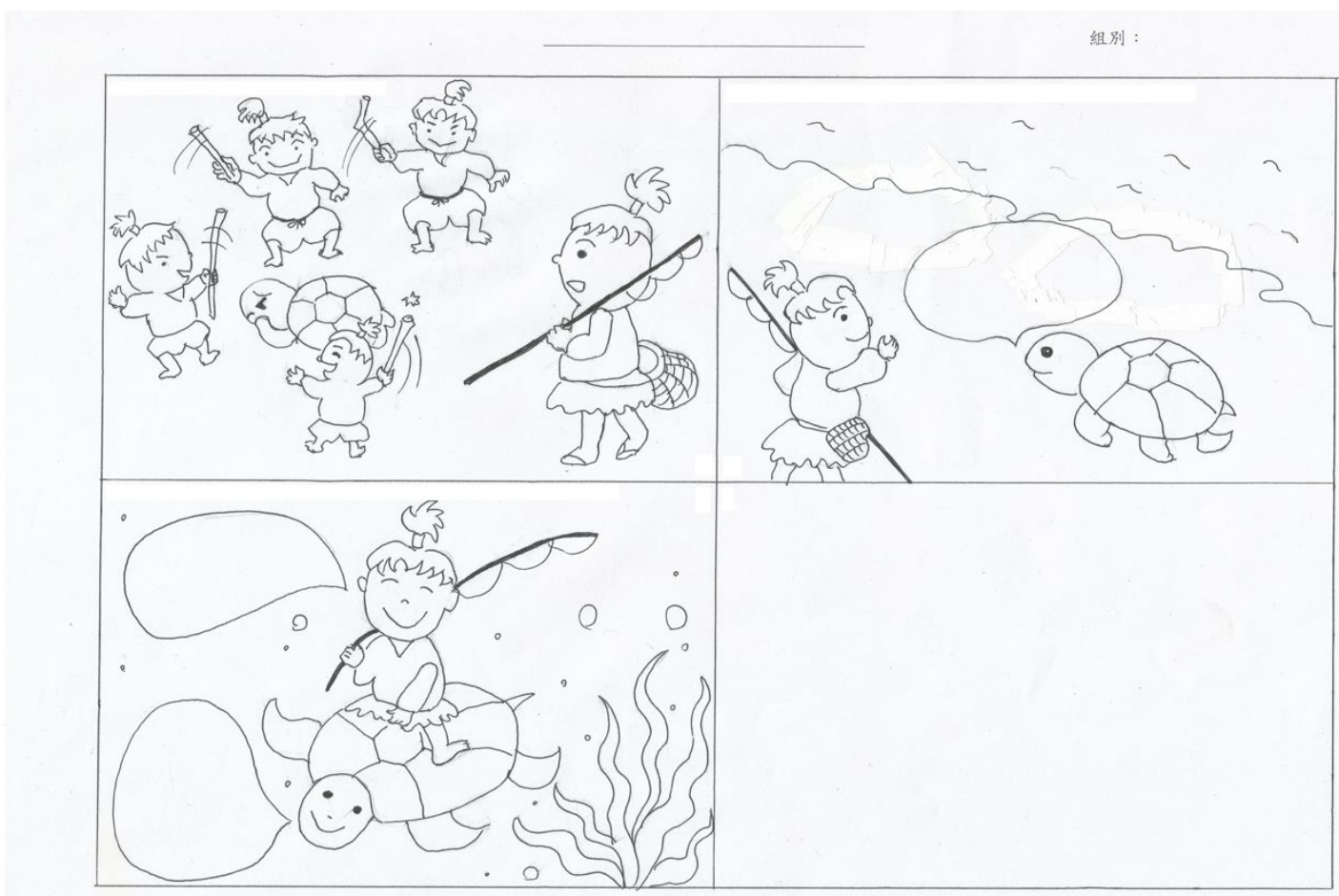

Figure 4. Four-grid comic about "a fisherman saved a sea turtle from being bullied by a bunch of children

Four students displayed weak perception of specific scientific concepts and limitations in connecting different concepts. According to the worksheets, these students either only drew a simple prototype or wrote down a function and material for solving a specific problem. For example, one student did not present his prototype with a drawing; he wrote a simple solution to the problem, such as giving a shark food to keep it from starving.

A four-grid comic was conducted in this stage to examine students' capability for creating a logical story based on the knowledge they had learned (see Figure 4). Most stories were about a fisherman who saved a sea turtle from being bullied by a bunch of children. To return the favor to the fisherman, the sea turtle served as the fisherman's tour guide and showed him its home ocean. Only one student mentioned damage such as marine waste that humans have caused to the ocean. 


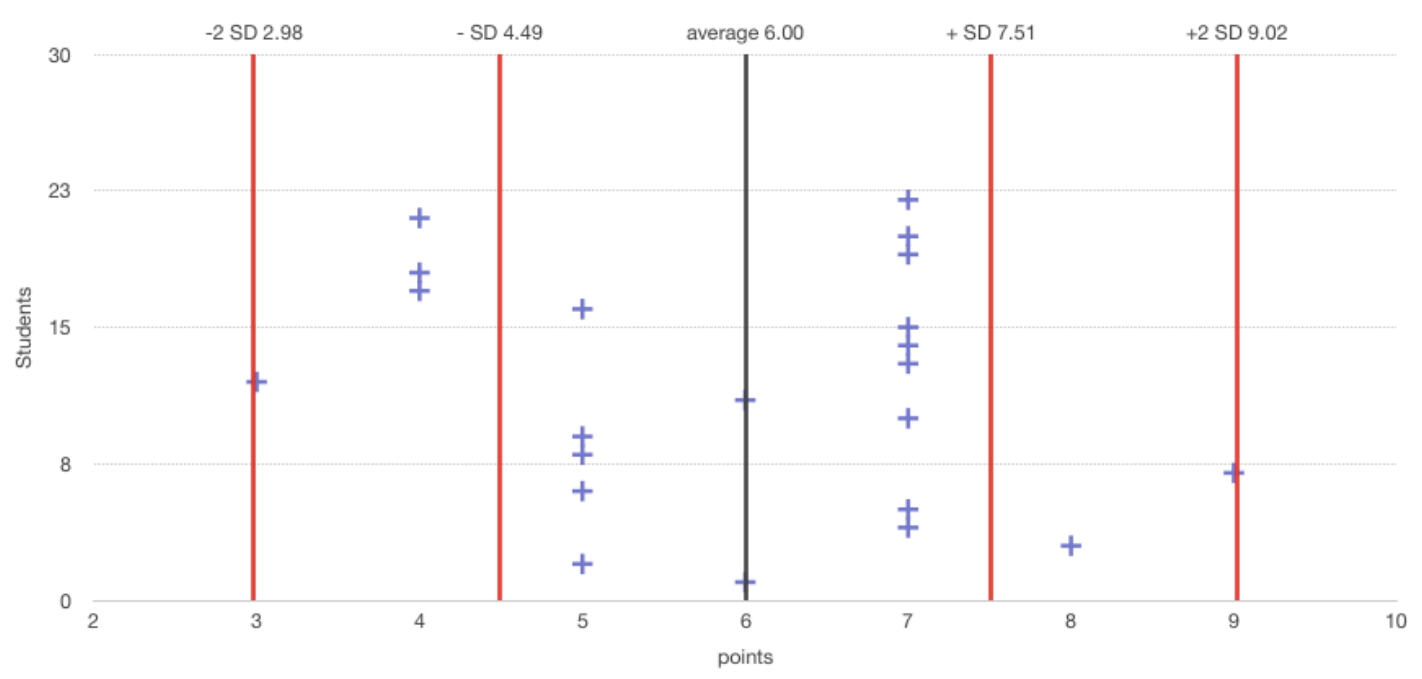

Figure 5. The distribution of students' performance in Virtual Practice stage

*Note: each + symbol represents a student $(N=22)$. Line 4.49 represents a standard deviation less than the mean; line 7.51 represents a standard deviation above the mean

\section{Student Performances in the Virtual Practice Stage}

After performing the activities intended to promote the development of scientific imagination, the students engaged in digital storytelling activities to reconstruct their scientific knowledge and thus, develop their scientific imagination. The findings of the analysis of the students' performances of storyboards in the Virtual Practice stage were associated with comprehension of scientific concepts and development of scientific imagination by creating a marine science story. The distribution of the scores for the students' storyboard performances showed that $73 \%$ of the students achieved scores between 5 and 7, reflecting a moderate capability for organizing and constructing the knowledge they learned and presented through stories (see Figure 5). These results indicate that students who performed within one standard deviation of the mean could design two or more characters with a simple narrative structure based on the science knowledge the students had learned. Most of the stories were related to a sea turtle being saved from suffocation and indigestion caused by marine waste.

Two of the 22 students scored 8 and 9, respectively, exceeding one standard deviation above the mean. Those students designed more than two or three characters on a storyboard, accompanied by a logical narrative and a plot based on the science knowledge they had learned. The students also coordinated the drawing and narrative to express their opinions. For example, one student's storyboard described a human-like robot who overfished, and marine organisms stood with one another to defend the robot and protect the ocean. Students who scored more than 8 points were not only able to design a logical and creative story but were also proficient at using pictures and words to tell a story that showed the students' comprehension of the scientific concept and development of scientific imagination.

Four students performed at one standard deviation lower than the average. Those students designed illogical storyboards. One student also was incapable of designing a narrative and did not create a logical scientific story. Some stories had no endings, and some did not have a coherent plot. Moreover, there was even incorrect marine science knowledge. For example, a student wrongly claimed that jellyfish is the main food for sea turtles.

\section{Student Performances in the Practice Stage}

Analyses in this stage were conducted with the goal of determining student abilities in collecting and utilizing various materials, such as images, music, and video clips, and demonstrating student achievement by creating digital stories with computer editing software. The distribution of the student performances shows that more than $90 \%$ of the students demonstrated significant capability in collecting and integrating a variety of materials such as images, subtitles and asides, music, video clips, and recordings of their own voices as narrators into a digital story and creating digital products with computer editing software (see Figure 6). Because of school facility constraints (Movie Maker was the only computer editing software package taught in class), all students used Movie Maker to create their digital stories. 


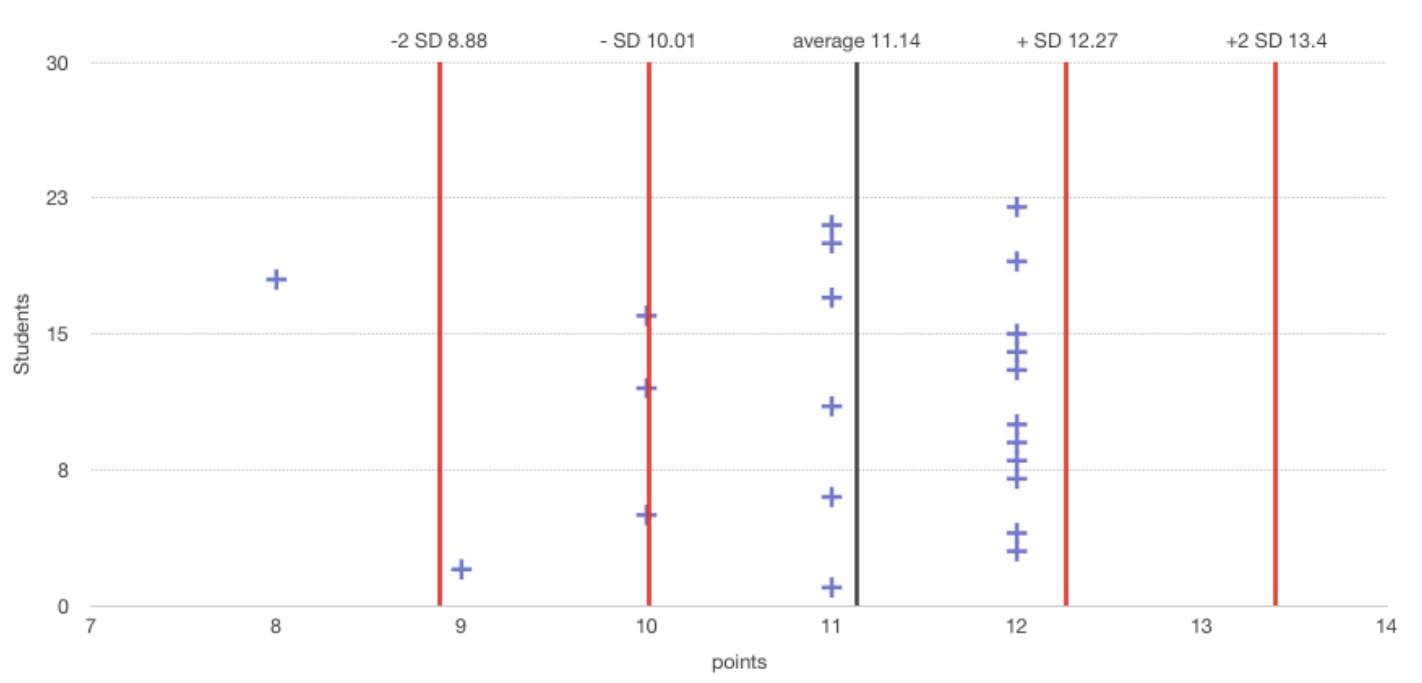

Figure 6. The distribution of student performance in the Practice stage

*Note: each + symbol represents a student $(N=22)$. Line 10.01 represents one standard deviation less than the average; line 12.26 represents one standard deviation more than the average

As shown in Figure 6, two students performed at a poorer level than the others. These students displayed limited ability in collecting dynamic materials and stated that it was hard to synchronize a background narrator with images or video clips. The students' digital stories also reflected incoherence and a deficiency of marine science knowledge.

After the students had finished designing their storyboards, they edited their scientific stories on the computer based on their storyboards. Fourteen students (about 68\%) were able to make logical and well-organized digital stories, and recorded narration in their digital stories to clearly express the stories and make them more fluent and logical. However, although the storyboards provided visual references when creating movies, the execution of the storyboards decreased because of the difficulty collecting related materials and unfamiliarity with the operation of computer editing software (Movie Maker).

\section{The Difficulty of Expressing Comprehension of Specific Scientific Concepts in the Dynamic Adjustment Stage}

Tracking student learning processes by assessing the students' artifacts with the digital storytelling scientific imagination framework, we found several common difficulties students encountered during the project, especially during the Dynamic Adjustment stage. This stage focused on refining particular ideas and developing student problem-solving capabilities by having the students draw prototypes of their inventions aimed at solving a selected marine science problem. The results indicated that most students were not proficient in describing the relationships among scientific concepts and creating science stories to express comprehension of specific scientific concepts. For example, one student could not specify what materials could be used to protect a shark from being hunted. Similar findings were presented in the Wang, Niemi, Ho, and Cheng (2017) study on learning progression in scientific imagination that compared the performance of Taiwanese and Finnish elementary school students on scientific imagination tasks. Wang et al. (2017) found that few Taiwanese and Finnish fifth- and sixth-grade students attain high levels of ability in the Virtual Practice stage that emphasizes the concept of students' association, transformation, and elaboration by evaluating students' ability to come up with solutions and illustrate the features and functions of the students' inventions. According to Ho et al. (2013), scientific imagination is influenced by internal and external factors. Students who are curious, observant, and open-minded show better scientific imagination; while external factors, such as teacher guidance, also can play an important role. Fleer (2013) illustrated the processes of developing students' scientific imagination and proposed that before creating inventions, a teacher should revisit students' experiences that allow deeper engagement and exploration of what the students have learned. Moreover, elaboration and transformation are formed through teachers' intentions in exploring concepts through the use of specific questioning. Wang et al. (2015) also mentioned that considerable class discussion and feedback are required in teaching activities. Liang and Chang (2014) stated that the characteristics agreeableness and self-efficacy have a significant impact on discovering relationships among ideas and crystallizing abstract concepts. In this study, students who attained a high level at this stage were found to 
fully engage in discussion with others. In other words, learning environments and personal characteristics may affect student achievement in the Dynamic Adjustment stage.

Meanwhile, elements of a learning environment, such as adopting assignments, curricular activities, or teambased collaborative learning activities, are crucial for concentrating student cognitive efforts and cultivating student capability for exploring and connecting different ideas (Herrmann, 2011; Hsu, Peng, Wang, \& Liang, 2014; Liang \& Chang, 2014). Use of individual worksheets may reduce student opportunities to explore and discover relationships among scientific concepts by limiting discussion or cooperation with others. Therefore, guiding questions and opportunities for discussion with other team members are highly recommended for improving student comprehension, transformation, and elaboration capability in the Dynamic Adjustment stage.

\section{The Opportunities and Challenges and of Using DST to Present Scientific Imagination}

Scientific imagination provides students with opportunities to boost their mental activities by connecting science phenomena with life experiences (Fleer, 2013; Ho et al., 2013). In addition, digital storytelling provides students with opportunities to reconstruct science knowledge related to scientific imagination the students have learned, including organizational capabilities, and conceptualization (Ohler, 2008; Ranieri \& Bruni, 2013). Digital storytelling requires students tell personal stories, and collect and share personal images that combine text, images, music, and voice into integrated digital stories that play the important role of supporting text to contextualize a story within a specific perspective and domain (Porto \& Belmonte, 2014).

From the Virtual Practice stage when students created storyboards to the Practice stage when the students were actually engaged in creating a digital story based on the storyboards, we observed improvements in the coherence and logic of the students' story creation. We also observed opportunities and challenges in using DST tools in the conceptualization, organization, and formation of developing scientific imagination, including students' capability of refining their storyboards, skills arranging plots, and telling stories based on the students' marine science knowledge.

\section{Opportunities}

We found that digital storytelling facilitates conceptualization, organization, and formation, three major components of scientific imagination for refining ideas and transforming them into novel inventions (Ho et al., 2013). These three components can develop students' imagination and transformation of creative ideas (Ho et al., 2013; Ren, Li, Zhang, \& Wang, 2012).

Conceptualization is the process of refining diverse ideas and formulating them into ideas and concepts. In the digital storytelling activities, students were required to select a marine science topic of interest according to the marine science knowledge they had learned to create their own digital story. This helped students revisit the marine knowledge they had learned and grasp different ideas while designing their story and in turn, facilitated conceptualization. For example, students learned the sea turtle's lifestyle, living habits, and how the animal's lifestyle and living habits are affected by human activities. The students refined their knowledge about sea turtles while formulating the concepts into a digital story by telling a story of how the sea predators, sea turtles, have been exterminated in the past few years which increased the number of jellyfish.

Organization refers to arranging marine science knowledge into a logical story. Students were asked to design a storyboard, including narratives and drawings. Ren et al. (2012) proposed that students express their creativity in different ways; for example, younger students tend to use drawing to express their thoughts. In the storyboard, drawings represent a structuring function, guiding students to organize the different concepts of the story and provide coherent narratives. In the process of designing storyboards and making digital storytelling products, students' organizational capability can be improved by sharing their stories with others and revising the storyboards. One student's storyboard draft was about a shark that had died because its fin was cut. A fisherman who had cut the shark's fin discovered that the shark was dead and felt sorry for his part in the death of the shark. At the end of the story, a table of shark fin cuisine was presented. After revising the story, one student knew better how to organize her story using proper arrangement. She reorganized her story to reflect that the fisherman sold the shark fin to a restaurant, and people enjoyed the delicious cuisine. In the meantime, the fisherman discovered that a shark could not survive without its fin so he regretted what he had done to the shark.

Formation required students to collect multimedia materials and use computer editing software to create digital storytelling products that conformed to their storyboard. Students were able to re-examine their marine science knowledge and story organization while also considering the coherence of the images, narrators, and background music. 


\section{Challenges}

We also found challenges in promoting students' digital storytelling. Creating a story with a computer editing software program can be very time-consuming. Moreover, a lack of related digital literacy in finding, evaluating, utilizing, sharing, and creating content using information technologies can create hardships for students' digital storytelling. Digital literacy is a competency of social practice, including reading, writing, and multimodal meaning-making through the use of digital technologies (Sefton-Green, Marsh, Erstad, \& Flewitt, 2016). Meyers, Erickson, and Small (2013) pointed out that digital technology has greatly influenced our thinking and behavior in formal and informal learning environments; thus, cultivating digital literacy is critical. Meyer et al. (2013) also stated that how we understand, assess, and value new digital literacies are the challenges and questions we encounter.

In this project's digital storytelling activities, students were provided with related photos, videos, and music. Most students used the materials provided to make their digital story in the limited time period except for two students who added their own drawings to the digital story. Many students were unfamiliar with collecting multimedia materials, such as images. Some students stated that it was hard to search for related images, particularly when many Internet images have copyright issues. A lack of familiarity with DST sometimes restricted students' imaginations and limited the information they were keen to convey. Therefore, giving students sufficient time to collect their own materials and to learn how to use DST tools is essential in a digital storytelling activity. This also means that the traditional class schedule with six to eight periods a day for fifty minutes each is not suitable for DST projects. Instead, block scheduling, in which a student attends a fewer number of classes for a longer period block of time, would be the optimal option for students engaged in DST projects.

Student performance in this study showed that the students were enthusiastic about learning how to use computer editing software. However, using computer software to create a story expressing specific concepts sometimes is difficult for students in recording the background narrator voice while typing subtitles.

\section{CONCLUSION}

This study was conducted to analyze students' learning processes for digital storytelling scientific imagination. To investigate the learning processes, we collected and analyzed data from 22 fourth-grade elementary school students through student artifacts, such as worksheets, storyboards, digital story products, and interviews. The results show that students reached a medium to high level in four of the five constructs of digital storytelling scientific imagination with the lowest level occurring in the Dynamic Adjustment stage. This stage reveals the ability of refining ideas and developing problem-solving skills through drawing a prototype for solving a specific marine science problem. Students at this stage exhibited little proficiency in describing relationships among science concepts by providing a prototype for creating a digital story. Therefore, it is crucial to conduct team-based collaborative learning activities and provide guiding instructions in the classroom that can cultivate student capabilities in connecting ideas and expressing their comprehension of specific science concepts (Hsu et al., 2014; Liang \& Chang, 2014).

Digital storytelling represents an optimal approach for facilitating scientific imagination by requiring students to reconstruct and organize science knowledge into a story (Ranieri \& Bruni, 2013). Based on these results, there are opportunities and challenges in digital storytelling scientific imagination. Digital storytelling can effectively be used by students while looking deeply into specific topics of science knowledge and is a method for developing students' scientific imagination. Challenges include the traditional class schedule and a lack of fluent digital literacy. These challenges are obstacles to implementing digital storytelling in a curriculum.

\section{ACKNOWLEDGEMENTS}

This research project was supported in part by the Ministry of Science and Technology, Taiwan; Grant No. MOST 104-2511-S-110-228-MY2. It was also supported by the Lee Teng-Hui Center for Government Studies from The Featured Areas Research Center Program within the framework of the Higher Education Sprout Project by the Ministry of Education (MOE) in Taiwan.

\section{REFERENCES}

Alrutz, M. (2013). Sites of possibility: applied theatre and digital storytelling with youth. Research in Drama Education: The Journal of Applied Theatre and Performance, 18(1), 44-57. https:/ / doi.org/10.1080/13569783.2012.756169

Chung, S. K. (2006). Digital storytelling in integrated arts education. The International Journal of Arts Education, 4(1), 33-50. Retrieved from http:/ / ed.arte.gov.tw/uploadfile/periodical/1320_arts_education41_033050.pdf 
Creswell, J. W., \& Plano Clark, V. L. (2011). Designing and conducting mixed methods research (2nd ed.). Los Angeles: SAGE Publications.

Duman, B., \& Göcen, G. (2015). The effect of the digital storytelling method on pre-service teachers' creative writing skills. Anthropologist, 20(1, 2), 215-222. Retrieved from https://www.researchgate.net/profile/ Gueler_Goecen_Kabaran/publication/291692903_The_Effect_of_the_Digital_Storytelling_Method_on_Pre -Service_Teachers'_Creative_Writing_Skills/links/586e0fb908aebf17d3a735bb/The-Effect-of-the-DigitalStorytelling-Method-on-Pre-Service-Teachers-Creative-Writing-Skills.pdf

Fleer, M. (2013). Affective imagination in science education: determining the emotional nature of scientific and technological learning of young children. Research of Science Education, 43, 2085-2106. https:/ / doi.org/10.1007/s11165-012-9344-8

Gregori-Signes, C. (2014). Digital storytelling and multimodal literacy in education. Porto Linguarum, 22, 237-250. Retrieved from https:/ / dialnet.unirioja.es/ servlet/articulo?codigo $=4772805$

Hacieminoglu, E. (2016). Elementary school students' attitude toward science and related variables. International Journal of Environmental \& Science Education, 11(2), 35-52. https:/ / doi.org/10.12973/ijese.2016.288a

Herrmann, M. (2011). Harnessing students' creativity and imagination as a means to effective engagement in sustainable education. Learning and Teaching in Higher Education, 5, 73-85.

Ho, H. C., Wang, C. C., \& Cheng, Y. Y. (2013). Analysis of the Scientific Imagination Process. Thinking Skills and Creativity, 10, 68-78. https:/ / doi.org/10.1016/j.tsc.2013.04.003

Hsu, Y. L., Peng, L. P., Wang, J. H., \& Liang, C. Y. (2014). Revising the imaginative capability and creative capability scales: Testing the relationship between imagination and creativity among agriculture students. International Journal of Learning, Teaching and Educational Research, 6(1), 57-70. Retrieved from http://ijlter.org/index.php/ijlter/article/view/118

Hung, C. M., Hwang, G. J., \& Huang, I. (2012). A project-based digital storytelling approach for improving students' learning motivation, problem-solving competence and learning achievement. Educational Technology $\mathcal{E}$ Society, 15(4), 268-279. Retrieved from http://www.jstor.org/stable/jeductechsoci.15.4.368

Jonassen, D. H. (2013). Transforming learning with technology. In: M. P. Clough, J. K. Olson \& D. S. Niederhauser (Eds.), The Nature of Technology (pp. 101-110). Sense Publishers, Rotterdam. https:/ / doi.org/10.1007/978-946209-269-3_7

Liang, C., \& Chang, C. C. (2014). Predicting scientific imagination from the joint influences of intrinsic motivation, self-efficacy, agreeableness, and extraversion. Learning and Individual Differences, 31, 36-42 https:/ / doi.org/10.1010/j.lindif.2013.12.013

Meyer, E. M., Erickson, I., \& Small, R. V. (2013). Digital literacy and informal learning environments: an introduction. Learning, Media and Technology, 38(4), 355-367. https:/ / doi.org/0.1080/17439884.2013.783597

Niemi, H., \& Multisilta. (2016). Digital storytelling promoting twenty-first century skills and student engagement. Technology, Pedagogy and Education, 25(4), 451-468. https:/ / doi.org/10.1080/1475939X.2015.1074610

Ohler, J. (2006). The world of digital storytelling. Educational leadership, 63(4), 44-47. Retrieved from https:/ /s3.amazonaws.com/academia.edu.documents/6349099/world_of_digital_storytelling_the_ohler_ j._.pdf?AWSAccessKeyId=AKIAIWOWYYGZ2Y53UL3A\&Expires=1534306441\&Signature=2Cv3G2YEEfT 4chrqX8xfGs22G44\%3D\&response-content-disposition=inline\%3B\%20filename\%3DThe_World_of_Digital _Storytelling.pdf

Ohler, J. (2008). Digital storytelling in the classroom: New media pathways to literacy, learning and creativity. Corwin Press, Thousand Oaks, CA.

Porto, M. D., \& Belmonte, I. A. (2014). From local to global: visual strategies of glocalisation in digital storytelling. Language \& Communication, 39, 14-23. https:/ / doi.org/10.1016/j.langcom.2014.05.001

Ranieri, M., Bruni, I. (2013). Mobile storytelling and informal education in a suburban area: a qualitative study on the potential of digital narratives for young second-generation immigrants. Learning, Media and Technology, 38(2), 217-235. https:/ / doi.org/10.1080/17439884.2013.724073

Reijnders, S. (2010). Places of the imagination. An ethnography of the TV detective tour. Cultural Geographies, 17(1), 37-52. https:// doi.org/10.1177/1474474009349998

Ren, F., Li, X., Zhang, H., \& Wang, L. (2012). Progression of Chinese students' creative imagination from elementary through high school. International Journal of Science Education, 34(13), 2043-2059. https:/ / doi.org/10.1080/09500693.2012.709334

Ribeiro, P. M. S. (2016). Developing intercultural awareness using digital storytelling. Language and Intercultural Communication, 16(1), 69-82. https:// doi.org/10.1080/14708477.2015.1113752 
Robin, B. R. (2008). Digital storytelling: a powerful technology tool for the $21^{\text {st }}$ century classroom. Theory into Practice, 47(3), 220-228. https:// doi.org/10.1080/00405840802153916

Sefton-Green, J., Marsh, J., Erstad, O., \& Flewitt, R. (2016). Establishing a research agenda for the digital literacy practices of young children: a white paper for COST action IS1410. Retrieved from http:/ / digilitey.eu/wpcontent/uploads/2015/09/DigiLitEYWP.pdf

Sharda, N. (2007). Applying movement oriented design to create educational stories. International Journal of Learning, 13, 177-184. https:/ / doi.org/10.18848/1447-9494/CGP/v13i12/ 45141

Smeda, N., Dakich, E., \& Sharda, N. (2014). The effectiveness of digital storytelling in the classrooms: a comprehensive study. Smart Learning Environments, 1(6), 1-21. https:/ / doi.org/10.1186/s40561-014-0006-3

University of Houston. (2011). The educational uses of digital storytelling. Retrieved from http:/ / digitalstorytelling.coe.uh.edu/pdfs/samplerubric.pdf

Wang, C. C., Ho, H. C., Cheng, Y. Y. (2015). Building a learning progression for scientific imagination: A measurement approach. Thinking Skills and Creativity, 17, 1-14. https:/ / doi.org/10.1016/j.tsc.2015.02.001

Wang, C. C., Niemi, H., Cheng, C. L., \& Cheng, Y. Y. (2017). Validation of learning progression in scientific imagination using data from Taiwanese and Finnish elementary school students. Thinking Skills and Creativity, 24, 73-85. https:/ / doi.org/10.1016/j.tsc.2017.02.014

Xu, Y., Park, H., \& Baek, Y. (2011). A new approach toward digital storytelling: An activity focused on writing selfefficacy in a virtual learning environment. Educational Technology \& Society, 14(4), 181-191. Retrieved from http:/ / www.jstor.org/stable/jeductechsoci.14.4.181

Yang, Y. T., \& Wu, W. C. (2012). Digital storytelling for enhancing student academic achievement, critical thinking, and learning motivation: A year-long experimental study. Computers $\mathcal{E}$ Education, 59, 339-352. https://doi.org/10.1016/j.compedu.2011.12.012

\section{http://www.ejmste.com}

